\title{
EFEKTIVITAS PENGGUNAAN MEDIA NERACA BILANGAN UNTUK MENINGKATKAN PEMAHAMAN KONSEP OPERASI PERKALIAN BAGI SISWA TUNAGRAHITA RINGAN
}

\author{
Aidilla Wyano Putri ${ }^{1}$, Damri Damri ${ }^{2}$ \\ ${ }^{1,2}$ Program Studi PLB, Universitas Negeri Padang \\ damrirajomdn18@gmail.com
}

\begin{abstract}
This study aims to prove that number balance media can improve understanding of the concept of multiplication operations with a maximum result of 10 in SLBN 02 Padang. This type of experimental research with the Single Subject Research approach uses the A-B-A design. Where A shows the baseline condition of the student's ability before being given intervention, then $\mathrm{B}$ is the period of intervention given to students, and $\mathrm{A}$ is the condition of the student after receiving the intervention called (A2). Overall the results of this study found that using a number balance media can improve the ability to understand the concept of multiplication operations with a maximum result of 10 for mild mentally retarded students with the results obtained in the A1 condition three times before using the number balance media are 17, 22, 22. Furthermore, the authors conducted ten treatments using a number balance media (B), the results obtained increased to 33, 44, 50, 50, 61, 67, 78, 83, 94, 94. Even students were able to obtain self-evaluation results ( A2) without using a number balance with three meetings the results obtained are $94,100,100$. The results of this study prove that the use of some balance media can improve understanding of the concept of multiplication operations with a maximum result of 10 for mild mentally retarded students.
\end{abstract}

Keywords: Number Balance Media, Multiplication Operation Concept, Mild Impairment.

\begin{abstract}
Abstrak
Penelitian ini bertujuan untuk membuktikan bahwa media neraca bilangan dapat meningkatkan pemahaman konsep operasi perkalian dengan hasil maksimal 10 di SLBN 02 Padang. Jenis penelitian eksperimen dengan pendekatan Single Subject Research menggunakan Disain A-B-A. Dimana A menunjukkan kondisi awal (baseline) kemampuan siswa sebelum diberikan intervensi, kemudian B adalah masa intervensi yang diberikan kepada siswa, dan A adalah kondisi siswa setelah mendapatkan intervensi yang disebut dengan (A2). Secara keseluruhan hasil penelitian ini didapati, bahwa dengan menggunakan media neraca bilangan dapat meningkatkan kemampuan memahami konsep operasi perkalian dengan hasil maksimal 10 bagi siswa tunagrahita ringan dengan hasil nilai yang diperoleh pada kondisi A1 dilakukan sebanyak tiga kali sebelum menggunakan media neraca bilangan adalah 17\%, 22\%, 22\%. Selanjutnya penulis melakukan sepuluh kali perlakuan dengan menggunakan media neraca bilangan (B) hasil yang didapatkan meningkat menjadi $33 \%$, $44 \%, 50 \%, 50 \%, 61 \%, 67 \%, 78 \%, 83 \%, 94 \%$, 94\%. Bahkan siswa mampu memperoleh hasil evaluasi kemampuan diri (A2) tanpa menggunakan media neraca bilangan dengan tiga kali pertemuan hasil yang diperoleh adalah 94\%, 100\%, 100\%. Hasil penelitian ini membuktikan bahwa penggunaan media neraca bilangan dapat meningkatkan pemahaman konsep operasi perkalian dengan hasil maksimal 10 bagi siswa tunagrahita ringan.
\end{abstract}

Kata kunci: Media Neraca Bilangan, Konsep Operasi Perkalian, Tunagrahita Ringan.

\section{PENDAHULUAN}

Pendidikan adalah suatu wadah bagi kehidupan seseorang masa sekarang dan masa yang akan datang. Seperti yang tercantum dalam (Undang-Undang Repbulik Indonesia Nomor 20 Tahun 2003, 2003) tentang sistem pendidikan pasal 5 ayat 2 bahwa pendidikan bekerja untuk menyiapkan pengetahuan, mengembangkan nilai, sikap, dan keterampilan atau kecakapan hidup untuk menyiapkan 
masa depannya serta pelayanan pendidikan tersebut bukan hanya diberikan kepada siswa normal namun juga di berikan kepada siswa berkebutuhan khusus.

Matematika adalah salah satu mata pelajaran yang berisi materi tentang kemampuan dasar menghitung siswa. Matematika juga berhubungan dengan ide-ide/konsep-konsep abstrak yang tersusun secara hirarkis (Sari, 2017). Lebih dari itu manfaat lain dari mempelajari pelajaran matematika adalah siswa diharapkan memiliki pemahaman dalam konsep operasi perhitungan, berpikir logis, dan sistematis. Pemahaman konsep merupakan salah satu kecakapan atau kemahiran matematika yang diharapkan dapat tercapai dalam belajar matematika (Kesumawati, 2008). Tiap-tiap konsep atau prinsip dalam matematika tersebut dapat disajikan dalam bentuk yang konkret agar mudah dipahami dengan baik bagi siswa (Aisyah \& Dkk, 2008).

Siswa berkebutuhan khusus memiliki kategori dan karakteristik, termasuk didalamnya kategori siswa tunagrahita. Siswa tunagrahita merupakan siswa yang pada umumnya memiliki karakteristik dengan IQ dibawah 70 dan umumnya pada kondisi itu, mereka mengalami kesulitan berfikir dan bernalar. Istilah populernya dikenal dengan RM (Retardasi Mental) yakni siswa dengan intelektual umum di bawah rata-rata yang berasal selama masa perkembangan anak dan dikaitkan dengan gangguan dalam perilaku adaptif (Whitley \& Neece, 2020).

Anak tunagrahita ringan memiliki IQ berkisaran 70-50, anak dengan retardasi mental ringan ini masuk ke dalam kategori tunagrahita mampu didik, dikategorikan mereka memiliki keterbatasan untuk mengikuti pembelajaran di sekolah reguler. Namun dengan keterbatasannya tersebut mereka masih memiliki potensi yang perlu di kembangkan seperti kemampuan untuk mengurus diri sendiri, membuat keterampilan, membaca, menulis, dan berhitung. Anak tunagrahita ringan adalah mereka sekelompok anak yang bisa mengikuti pendidikan khusus karena hanya memiliki kecerdasan, adaptasi, serta sosial yang terlambat (Yetti \& Damri, 2014).

Sesuai dengan kurikulum terutama kurikulum anak Tunagrahita (Kompetensi Inti dan Kompetensi Dasar Matematika SMPLB Tunagrahita, n.d.) kelas VII/C Semester II memuat materi matematika tentang mengenal operasi perkalian dan pembagian sampai 10. Dengan Kompetensi Dasar 3.2 yang berisi mengenal operasi perkalian dan pembagian sampai 10 serta 4.2 yang isinya mengenai melakukan operasi perkalian dan pembagian sampai 10.

Perkalian yaitu proses aritmatika dasar yang dimana satu bilangan dilipat gandakan sesuai dengan bilangan pengalinya. Secara sederhana perkalian dapat dikatakan sebagai penjumlahan berulang. Menurut (Yoppy, 2014) konsep dari perkalian adalah melakukan penjumlahan secara berulang-ulang. Maka untuk memahami konsep perkalian, siswa harus menguasai konsep dari penjumlahan. Pada prinsipnya operasi bilangan "a" dikali "b" atau "a" dan "b", dimana suku "a" yang menjadi penjumlahan berulang ulang dari suku " $b$ ". Dengan rumus: $a \times b=b+b+b+b+b$ (a suku). Jika a x b = c, maka c dinamakan sebagai hasil.

Berdasarkan studi pendahuluan dalam bentuk observasi yang peneliti lakukan pada bulan Oktober-November 2019. Peneliti mengidentifikasi seorang siswa laki-laki berumur 15 tahun dan 
duduk dikelas 1 SMPLB yang berinisial NA bersekolah di SLB N 02 Padang, peneliti melakukan identifikasi dengan melakukan test secara klasikal. Hasil tes diketahui ada 4 siswa yang melakukan tes. Salah satunya anak yang berinisial NA mendapat nilai terendah. Dari 10 soal perkalian anak hanya mampu menjawab soal sebanyak 7 soal, dengan benar 5 soal dan 2 soal dijawab salah serta 3 soal lainnya tidak dijawab.

Kemudian peneliti melanjutkannya dengan melakukan asesmen terhadap NA, sebelum peneliti memberikan soal perkalian, peneliti memberikan soal penjumlahan dan pengurangan terlebih dahulu kepada siswa dan didapatkan siswa mampu menjawab soal penjumlahan dan penggurangan. Selanjutnya peneliti memberikan soal perkalian dengan hasil maksimal 10. Didapatkan bahwa siswa salah dalam menjawab soal yang diberikan, contoh soal yang diberikan seperti 5 x 2 ? dan dijawab oleh siswa 7, contoh soal yang lainnya seperti 2 x 3 ? dijawab oleh siswa 5, 3 × 3 ? dijawab oleh siswa 6, 4 × 2 ? dijawab siswa 6. Dapat dilihat bahwa siswa melakukan penjumlahan dalam perkalian, sedangkan untuk perkalian memiliki konsep yakni penjumlahan yang berulang. Dan disini peneliti melihat bahwa siswa belum memahami konsep dalam operasi perkalian.

Media neraca bilangan merupakan salah satu media pembelajaran yang dapat mengembangkan potensi anak pada dimensi visual (Nuraini, 2013). Media neraca bilangan yang digunakan dalam penelitian ini terbuat dari kayu. Kayu tersebut akan dibuat berbentuk seperti timbangan. Media neraca bilangan merupakan salah satu media pembelajaran yang bisa digunakan oleh siswa tunagrahita, karena media neraca bilangan ini bisa memudahkan siswa dalam memahami konsep matematika terutama dalam konsep perkalian. Siswa tunagrahita mempunyai keterbatasan dalam hal penalaran, berdasarkan uji dari hasil penelitian terdahulu bahwa media ini telah banyak mengatasi masalah berhitung dalam konteks perkalian. Penelitian ini bertujuan membuktikan bahwa Pemahaman Konsep Operasi Perkalian dengan Hasil Maksimal 10 dapat meningkat melalui media Neraca bilangan pada Siswa Tunagrahita Ringan di kelas VII SLB 02 Padang.

\section{METODE}

Jenis penelitian ini adalah eksperimen yang berbentuk SSR (Single Subject Research). (Damri, 2013) mengemukakan bahwa penelitian eksperimen merupakan suatu percobaan yang dilakukan untuk meneliti suatu peristiwa atau gejala yang muncul terhadap suatu kondisi tertentu, penelitian ini menggunakan eksperimen pendekatan Single Subject Research. Single Subject Research yakni metode penelitian yang menggunakan subjek sebagai kontrol sendiri dengan mengubah intervensi yang disajikan kepadanya dan dengan hati-hati melalui pengamatan atau pengukuran berulang menurut (Peter, 2016) disain yang digunakan yaitu A - B - A. Dapat dilihat pada bagan Alir dibawah ini. 


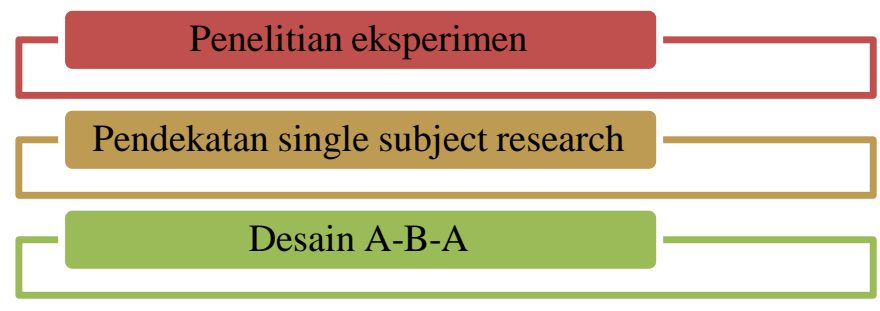

Gambar 1. Bagan Alir Penelitian

Dimana A merupakan kondisi awal atau disebut dengan fase (baseline) yang tampak pada kondisi ini adalah kemampuan memahami konsep operasi perkalian dengan hasil 10 sebelum intervensi diberikan. Sedangkan B yaitu fase yang disebut dengan kondisi intervensi yang diberikan media neraca bilangan untuk memahami konsep operasi perkalian dengan hasil maksimal 10 pada siswa. Terakhir adalah fase (A2) ialah pengukuran behavior setelah tidak diberikan intervensi. Seluruh hasil data yang diperoleh dihitung dengan bantuan Ms. Excel. Pencatatan data menggunakan instrumen penelitian yang terdiri dari tiga kriteria penilaian yaitu B (bisa), BDB (bisa dengan bantuan) dan TD (tidak bisa). Data yang diperoleh kemudian dijabarkan dalam bentuk grafik, dan dianalisis menggunakan teknik analisis visual grafik yang mencakup analisis dalam kondisi dan antar kondisi. Penelitian dilakukan sebanyak 16 kali pertemuan yang diawali dari tanggal 8 September sampai 30 September 2020.

\section{HASIL}

Berdasarkan tujuan penelitian yaitu efektivitas penggunaan media neraca bilangan untuk meningkatkan pemahaman konsep operasi perkalian dengan hasil maksimal 10 bagi siswa tunagrahita ringan, maka peneliti menggunakan penelitian eksperimen dengan pendekatan single subject research (SSR) desain A-B-A. Dimana A menunjukkan bagaimana kondisi awal (baseline) kemampuan siswa sebelum diberikan intervensi, kemudian B adalah masa intervensi yang diberikan kepada siswa, dan A adalah kondisi siswa setelah mendapatkan intervensi yang disebut (A2). Berikut penjabaran tiap-tiap kondisi tersebut.

\section{Tabel 1.}

Tabel Kemampuan Memahami Konsep Operasi Perkalian dengan Hasil Maksimal 10

\begin{tabular}{c|l|c|c}
\hline No. & Hari/Tanggal & Pengamatan & Persentase \\
\hline 1. & Selasa/8 September 2020 & I & $17 \%$ \\
\hline 2. & Rabu/9 September 2020 & II & $22 \%$ \\
\hline 3. & Kamis/10 September 2020 & III & $22 \%$ \\
\hline 4. & Senin/14 September 2020 & IV & $33 \%$ \\
\hline 5. & Selasa/15 September 2020 & V & $44 \%$ \\
\hline 6. & Rabu/16 September 2020 & VI & $50 \%$ \\
\hline 7. & Kamis/17 September 2020 & VII & $50 \%$ \\
\hline 8. & Jumat/18 September 2020 & VIII & $61 \%$ \\
\hline 9. & Senin/21 September 2020 & IX & $67 \%$ \\
\hline 10. & Selasa/22 September 2020 & X & $78 \%$ \\
\hline
\end{tabular}




\begin{tabular}{c|l|c|c}
\hline 11. & Rabu/23 September 2020 & XI & $83 \%$ \\
\hline 12. & Kamis /24 September 2020 & XII & $94 \%$ \\
\hline 13. & Jumat/25 September 2020 & XIII & $94 \%$ \\
\hline 14. & Senin/28 September 2020 & XIV & $94 \%$ \\
\hline 15. & Selasa/29 September 2020 & XV & $100 \%$ \\
\hline 16. & Rabu/30 September 2020 & XVI & $100 \%$ \\
\hline
\end{tabular}

Berdasarkan grafik diatas dapat dilihat Kemampuan Memahami Konsep Operasi perkalian dengan Hasil Maksimal 10 persentase yang didapatkan pada Baseline (A1) sebelum intervensi diberikan didapatkan persentase 17, 22, 22 selama tiga hari pengamatan. Kedua, hasil analisis pada kondisi intevensi (B) saat menggunakan media neraca bilangan persentase yang didapatkan 33, 44, $50,50,61,67,78,83,94,94$ pengamatan dilakukan selama sepuluh hari. Ketiga hasil analisis pada kondisi Baseline (A2) setelah diberikan intervensi didapatkan persentase 94, 94, 100.

Setelah seluruh data diperoleh maka data tersebut dianalisis berdasarkan setiap kondisi pengamatan menggunakan analisis visual. Dalam menganalisis data menggunakan metode analisis visual ada beberapa hal yang perlu diperhatikan, yakni: banyaknya data poin disetiap kondisi, banyak variabel terikat yang hendak diubah, tingkat stabilitas, perubahan level data, serta arah perubahan dalam kondisi maupun antar kondisi (Sunanto, 2005). Pada penelitian ini, data dianalisis dengan analisis dalam kondisi dan analisis antar kondisi. Berikut hasil data analisis dalam kondisii

\section{Tabel 2.}

Hasil analisis dalam kondisi

\begin{tabular}{|c|c|c|c|c|}
\hline No. & Kondisi & $\mathbf{A 1}$ & $\mathbf{B}$ & $\mathbf{A 2}$ \\
\hline 1. & Panjang Kondisi & 3 & 10 & 3 \\
\hline 2. & $\begin{array}{l}\text { Estiminasi } \\
\text { Kecenderungan Arah }\end{array}$ & & & \\
\hline 3. & $\begin{array}{l}\text { Kecenderungan } \\
\text { Stabilitas }\end{array}$ & Stabil & Tidak Stabil & Stabil \\
\hline 4. & $\begin{array}{l}\text { Kecenderungan jejak } \\
\text { data }\end{array}$ & & & \\
\hline 5. & $\begin{array}{l}\text { Level Stabilitas dan } \\
\text { Rentang }\end{array}$ & $17-22$ & $33-94$ & $94-100$ \\
\hline 6. & Level Perubahan & $\begin{array}{l}22-17=5 \\
(+)\end{array}$ & $\begin{array}{l}94-33=61 \\
(+)\end{array}$ & $\begin{array}{l}100-94=6 \\
(+)\end{array}$ \\
\hline
\end{tabular}

Berdasarkan tabel 2 diatas diketahui panjang kondisi merupakan hari pengamatan yang dilakukan pada setiap kondisi yakni enam belas hari pengamatan. Pada baseline (A1) kondisi natural siswa didapatkan estimasi kecenderungan arah yang sedikit menaik dengan nilai 5\%. Pada kondisi intervensi dengan menggunakan media neraca bilangan didapatkan estimasi kecenderunan arah yang 
Efektivitas Penggunaan Media Neraca Bilangan Untuk Meningkatkan Pemahaman Konsep Operasi Perkalian Bagi

cenderung meningkat dengan nilainnya $61 \%$. Dan pada kondisi Baseline setelah menggunakan media neraca bilangan hasil yang didapat sedikit meningkat yakni dengan nilai $6 \%$. Selanjutnya pada hasil analisis antar kondisi:

\section{Tabel 3.}

Hasil analisis antar kondisi

\begin{tabular}{|l|l|l|}
\hline No. & Kondisi & A1 : B : A2 \\
\hline 1. & Jumlah variabel yang diubah & 1 \\
\hline 2. & Perubahan kecenderungan arah & \\
\hline 3. & $\begin{array}{l}\text { Perubahan kecenderungan } \\
\text { stabilitas }\end{array}$ & $\begin{array}{l}\text { Stabil } \\
\text { Belum stabil } \\
\text { Stabil }\end{array}$ \\
\hline 4. & Level perubahan B/A1 & $22-33=-11$ \\
\hline 5. & Level perubahan B/A2 & $100-94=6$ \\
\hline 6. & Persentase overlap A1/B & $30 \%$ \\
\hline 7. & Persentase overlap A2/B & $20 \%$ \\
\hline
\end{tabular}

Berdasarkan tabel 3 diatas diketahui jumlah variabel yang diubah pada penelitian ini adalah 1, yaitu kemampuan memahami konsep operasi perkalian dengan hasil maksimal 10 bagi siswa tunagrahita ringan. Perubahan kecenderungan arah pada Baseline (A1) kemampuan awal siswa dalam memahami konsep operasi perkalian dengan hasil maksimal 10 terlihat sedikit naik (+). Pada kondisi intervensi kemampuan memahami konsep operasi perkalian dengan hasil maksimal 10 saat menggunakan media neraca bilangan terlihat meningkat (+). Pada kondisi Baseline (A2) kemampuan siswa setelah menggunakan media neraca bilangan sedikit meningkat $(+)$. Perubahan level pada baseline (A1) dengan intervensi adalah negatif (-11) dan pada baseline (A2) dengan intervensi adalah positif (+6). Pada baseline (A1) dengan intervensi didapatkan persentase overlap $30 \%$ dan pada kondisi baseline A2 dengan intervensi persentase overlap yang didapatkan adalah 20\%. Dengan semakin kecilnya persentase pada overlap maka pegaruh intervensi pada perubahan perilaku semakin membaik (Sunanto, 2005). Berarti hal ini membuktikan bahwa upaya dalam meningkatkan kemampuan memahami konsep operasi perkalian dengan hasil maksimal 10 menggunakan media neraca bilangan dapat membaik. 


\section{KESIMPULAN}

Berdasarkan pembahasan dari hasil penelitian ini dapat di tarik uraian permasalahan yaitu penggunaan media Neraca Bilangan dapat meningkatkan pemahaman konsep operasi perkalian dengan hasil maksimal 10 bagi siswa tunagrahita ringan kelas VII di SLB N 02 Padang. Hal ini terbukti dari hasil pengamatan yang dilakukan sebanyak 16 kali dengan kondisi Baseline A1 masih rendah, namun pada saat Intervensi (B) diberikan mengalami peningkatan, dan selanjutnya pada kondisi Baseline (A2) kemampuan siswa semakin meningkat menjadi 100\% dan cenderung stabil. Berdasarkan hasil dalam kondisi dan analisis antar kondisi yang diperoleh dapat disimpulkan bahwa kemampuan memahami konsep operasi perkalian dengan hasil maksimal 10 meningkat melalui media neraca bilangan pada siswa tunagrahita ringan kelas VII di SLB N 02 Padang. Hasil penelitian juga didukung oleh penelitian (Puspitasari et al., 2016)

\section{DAFTAR PUSTAKA}

Aisyah, \& Dkk. (2008). Mengembangkan Pembelajaran Matematika di SD. Jakarta: Depdiknas.

Damri. (2013). Meningkatkan Kemampuan Mengenal Huruf Vokal Melalui Laptop Mainan Anak Untuk Anak Tunagrahita Ringan Kelas II Di SLB Perwari Padang. 2, 609-621.

Kesumawati, N. (2008). Pemahaman Konsep Matematik dalam Pembelajaran Matematika. 229-235.

Kompetensi Inti dan Kompetensi Dasar Matematika SMPLB Tunagrahita. (n.d.). 1017-1021.

Nuraini. (2013). Upaya Meningkatkan Aktivitas dan Hasil Belajar Siswa tentang Perkalian dan Pembagian Melalui Metode Diskusi Kelompok dengan Menggunakan Alat Peraga Neraca Bilangan Kelas II SDN 14 Curup.

Peter, K. (2016). Single Sybject Research Method: The Need Simplification. 4(6), 68-95.

Puspitasari, R. D., Usada, Istiyati, S., \& Kamsiyati, S. (2016). Penggunaan Media Neraca Bilangan Untuk Meningkatkan Pemahaman Konsep Operasi Perkalian Dan Pembagian.

Sari, P. (2017). Pemahaman Konsep Matematika Siswa Pada Materi Besar Sudut Melalui Pendekatan PMRI. II(1), 41-51.

Sunanto, J. (2005). Pengantar Penelitian dengan Subyek Tunggal. Jepang: University of Tsukuba.

Undang-Undang Repbulik Indonesia Nomor 20 Tahun 2003. (2003). 0932(1), 147-173.

Whitley, R., \& Neece, C. (2020). Mental Retardation: Early Identification and Prevention Discover the world's View Nursing care study: trigger Parenting Stress and Emotion Dysregulation among Children with Developmental Delays: The Role of Par ... J151026 Job Evaluation Method Retar. 2020.

Yetti \& Damri. (2014). Meningkatkan Keterampilan Membuat Box File Melalui Metode Demonstrasi Pada Anak Tunagrahita Ringan Kelas VI SLB Binar Tarusan. Jurnal Ilmiah Pendidikan Khusus, $3(1), 11-22$.

Yoppy, W. (2014). Serial Matematika untuk PGSD Bilangan Cacah dan Bulat Sebuah Tinjauan Konsep dan Instruksional dalam Pembelajaran. Alfabeta. 